\title{
Surgical treatment of elderly patients with infrarenal abdominal aortic aneurysm
}

\author{
E Cappello ${ }^{*}$, F Spinetti, M Di Lorenzo, E Franco \\ From XXIII Annual Meeting of the Italian Society of Geriatric Surgery \\ Lecce, Italy. 2-4 December 2010
}

\section{Background}

The traditional surgical treatment for abdominal aortic aneurysm (AAA) is now well codified in vascular surgery with a perioperative mortality rate that has gradually declining in recent years. The introduction of endovascular techniques has led the indications for surgery to be reviewed. The results of surgery in patients over eighty are fairly well defined: it is encoded that age affects only a small part of the immediate results in terms of overall mortality, while it is a significant factor in increasing rates of perioperative major morbidity, in particular cardiac and respiratory diseases. The purpose of this article is to assess the octogenarian patients who are not candidates for treatment with endoprosthesis.

\section{Materials and methods}

The characteristics of the proximal neck, distal and size influence the feasibility of enablers and results of endovascular treatment. All patients who do not respect these features are handled by us with traditional surgery. The high prevalence of ischemic heart disease in patients with AAA is a major cause of morbidity and mortality $(46.2 \%$ of early mortality, late mortality of $17.7 \%$ ) in the surgical treatment of AAA (Won et al. Validation of selective cardiac evaluation prior to aortic aneurysm repair).

Literature data show that if coronary angiography is performed routinely in patients with AAA awaiting surgery, the frequency of hemodynamically significant stenosis varies from 46 to $75 \%$. (Utoh et al.) For the reasons that all patients, twice in our experience can not be treated by endovascular undergo coronary angiography before surgery for AAA.

\footnotetext{
* Correspondence: enrico.cappello@yahoo.it

Unit of Vascular Surgery Rummo Hospital, Benevento, Italy
}

\section{Results}

In our series, since 2002, we have operated on 560 patients of which 282 are of AAA ultra octogenarians.

Of these, 224 have been processed with endoprosthesis and 58 to surgical repair of aortic graft. $100 \%$ of those operated with traditional surgery had a short proximal neck, in $70 \%$ with the involvement of a renal artery aneurysm. $42 \%$ of all patients had a coronary heart disease that was treated preoperatively with coronary stents. Among the octogenarians the operative mortality of patients undergoing surgical repair for AAA was $4 \%$.

\section{Conclusions}

The advent of endoprotesis has certainly improved the survival rate and morbidity of elderly patients with risk of AAA rupture. A selection of the patients, careful study of cardiac risk and treatment of coronary artery disease and carotid artery before surgery are prerequisites to reduce perioperative complications.

Published: 24 August 2011

\section{References}

1. El-Sabrout RA, Reul GJ, Cooley DA: Outcome after simultaneous abdominal aortic aneurysm repair and aortocoronary bypass. Ann Vasc Surg 2002, 16(3):321-30.

2. J A, Browner D, Hye RJ, Won A: Validation of selective cardiac evaluation prior to aortic aneurysm repair. Arch Surg 1998, 133(8):833-8.

3. Utoh J, Goto H, Hirata T, Hara M, Kitamura N: Routine coronary angiography prior to abdominal aortic aneurysm repair: incidence of silent coronary artery disease. Panminerva Med 1998, 40(2):107-9.

4. Koskas F, Kieffer E Ann: Surgery for ruptured abdominal aortic aneurysm: early and late results of a prospective study by the AURC in 1989. VasC Surg 1997, 11(1):90-9.

5. Badran MF, Gould DA, Raza I, McWilliams RG, Brown O, Harris PL, GillingSmith GL, Brennan J, White D, Meakin S, Rowlands PC: Aneurysm neck diameter after endovascular repair of abdominal aortic aneurysms. J Vasc Interv Radiol 2002, 13:887-92.

6. Takahashi J, Okude J, Gohda T, Murakami T, Hatakeyama M, Sasaki S, Yasuda $\mathrm{K}$ : Coronary artery bypass surgery in patients with abdominal
C 2011 Cappello et al; licensee BioMed Central Ltd. This is an open access article distributed under the terms of the Creative Commons Attribution License (http://creativecommons.org/licenses/by/2.0), which permits unrestricted use, distribution, and reproduction in any medium, provided the original work is properly cited. 
aortic aneurysm: detection and treatment of concomitant coronary artery disease. Ann Thorac Cardiovasc Surg 2002, 8(4):213-9.

7. Biancari F, Ylönen K, Anttila V, Juvonen J, Romsi P, Satta J, Juvonen TJ: Durability of open repair of infrarenal abdominal aortic aneurysm: a 15year follow-up study. Vasc Surg 2002, 35(1):87-93.

8. Menard MT, Chew DK, Chan RK, Conte MS, Donaldson MC, Mannick JA, Whittemore AD, Belkin MJ: Outcome in patients at high risk after open surgical repair of abdominal aortic aneurysm. Vasc Surg 2003, 37(2):285-92.

9. Upchurch GR Jr, Proctor MC, Henke PK, Zajkowski P, Riles EM, Ascher MS, Eagleton MJ, Stanley JC: Predictors of severe morbidity and death after elective abdominal aortic aneurysmectomy in patients with chronic obstructive pulmonary disease. J Vasc Surg 2003, 37(3):594-9.

10. Laheij RJ, Buth J, Harris PL, Moll FL, Stelter WJ, Verhoeven EL: Need for secondary interventions after endovascular repair of abdominal aortic aneurysms. Intermediate-term follow-up results of a European collaborative registry (EUROSTAR). Br J Surg 2000, 87(12):1666-73.

11. Buth J, Laheij RJ: Early complications and endoleaks after endovascular abdominal aortic aneurysm repair: report of a multicenter study. J Vasc Surg 2000, 31:134-46.

12. Agus GB, Mondani P, Santuari D, Cappelletti M: Pararenal aortic aneurysms: definition, classification, directions for surgery. Ann Ital Chir 2004, 75(2):137-41

13. Steinmetz E, Abello N, Kretz B, Gauthier E, Bouchot O, Brenot R: Analysis of outcome after using high-risk criteria selection to surgery versus endovascular repair in the modern era of abdominal aortic aneurysm treatment. Eur J Vasc Endovasc Surg 2010, 39:403-9.

14. Sicard GA, Zwolak RM, Sidawy AN, White RA, Siami FS, Society for Vascular Surgery Outcomes Committee: Endovascular abdominal aortic aneurysm repair: long-term outcome measures in patients at high-risk for open surgery. J Vasc Surg 2006, 44:229-36.

15. Knott AW, Kalra M, Duncan AA, Reed NR, Bower TC, Hoskin TL, Oderich GS, Gloviczki P: Open repair of juxtarenal aortic aneurysms (JAA) remains a safe option in the era of fenestrated endografts. J Vasc Surg 2008, 47(4):695-701.

16. Wahlgren CM, Malmstedt J, Swedish Vascular Registry: Outcomes of endovascular abdominal aortic aneurysm repair compared with open surgical repair in high-risk patients: results from the Swedish Vascular Registry. J Vasc Surg 2008, 48(6):1382-8.

17. Zarins CK, Crabtree T, Bloch DA, Arko FR, Ouriel K, White RA: Endovascular aneurysm repair at 5 years: Does aneurysm diameter predict outcome? J Vasc Surg 2006, 44:920-29.

18. Shahidi S, Schroeder TV, Carstensen M, Sillesen H: Outcome and survival of patients aged 75 years and older compared to younger patients after ruptured abdominal aortic aneurysm repair: do the results justify the effort? Ann Vasc Surg 2009, 23(4):469-77.

19. Elkouri S, Gloviczki P, McKusick MA, Panneton JM, Andrews J, Bower TC, Noel AA, Harmsen WS, Hoskin TL, Cherry K: Perioperative complications and early outcome after endovascular and open surgical repair of abdominal aortic aneurysms. J Vasc Surg 2004, 39(3):497-505.

doi:10.1186/1471-2318-11-S1-A6

Cite this article as: Cappello et al:: Surgical treatment of elderly patients with infrarenal abdominal aortic aneurysm. BMC Geriatrics 2011 11(Suppl 1):A6.

\section{Submit your next manuscript to BioMed Central and take full advantage of:}

- Convenient online submission

- Thorough peer review

- No space constraints or color figure charges

- Immediate publication on acceptance

- Inclusion in PubMed, CAS, Scopus and Google Scholar

- Research which is freely available for redistribution 